\title{
Digitalization as a resource for updating the Soviet
}

\author{
V.V. Skorobogatskiy* \\ Ural Institute of Management - branch of RANEPA, Ekaterinburg, Russia
}

\begin{abstract}
One of the topical tasks of the development of Russian society is the modernization of the public administration system, bringing the state structure in accordance with the requirements of a new social reality - the transition from an industrial to an information society. The article shows that the administrative-bureaucratic model of public administration, introduced over two decades, has been undergoing a digital transformation in recent years. The main direction of digitalization is the sphere of services that the state provides to citizens, organizations and businesses. It is noted that the usage of modern technologies does not lead to an increase in the efficiency of public administration, and its low quality becomes the main factor hindering economic growth and the formation of human capital. As a result of the study, it is concluded that the reason for the low quality of public administration and the contradictory consequences of its digitalization is that, in terms of its main characteristics, Russian society remains Soviet. The archaization of social, economic and political institutions experienced at the turn of the 1990s-2000s in line with the political course of abandoning market and democratic reforms has created a situation of institutional trap in which Russian society is today and which prevents the effective usage of new generation technologies.
\end{abstract}

\section{Introduction}

The idea of digitalization in Russia has gained total significance today. It is considered as a way to modernize ("catch up and overtake!") not only the economy, but also the spheres of social communication, culture, education, healthcare and, finally, public administration $[1$, pp. 16-17; 5]. In other words, this idea has acquired a comprehensive character and is applied in various areas of public life without taking into account whether there are necessary and sufficient conditions for its implementation, primarily institutional, and not only technical, financial and personnel ones. Digitalization has become a kind of magic wand, a magical means by which it is supposedly possible to find a way out of the dead ends and uncertainties of the current state, to achieve a miraculous transformation of reality. This practice has a famous predecessor, Stalin, who in tipping points actively and successfully used a fetish called "new, higher technology" [8, pp. 274-276]. Fantastic realism was a trend not only in Russian literature (Gogol, Dostoevsky, Bulgakov), but also in politics.

\footnotetext{
* Corresponding author: skorobogatskiy-vv@,ranepa.ru
} 
But with this approach, not only institutional, but also political factors and approaches to the implementation of the planned innovations remain in the shadow. Moreover, in the last two decades, distancing from public policy has been a fully conscious attitude, if you will, a kind of political course, in line with which modernization programs are based on replacing political technologies with other, ideologically neutral ones. More precisely, allowing one or another of their ideological content, depending on the conjuncture. And it seems that digital technologies are ideally suited for these purposes. But won't digitalization suffer the fate of other initiatives abandoned halfway through, as happened with a number of previous projects of a long-term scale? Neither the idea of strengthening the vertical of power nor the national anti-corruption plan have become strategic programs of state policy. Having played the role of a manifesto at first, opening the era of new government, they soon underwent routine and turned into a set of plans and reports compiled annually.

\section{Research methodology}

In this situation, the question of the potential and boundaries of technological innovation, the relationship of technology, on the one hand, politics, economics, culture and societality, taken together as a whole (society), and separately, on the other hand, becomes relevant. But asking such a question takes us out the boundaries of the methodology itself, since it affects a broader area than the problem of choosing and justifying a particular method or approach. We are talking here about fundamental things, namely, the long overdue change of the metamethodological platform in the domestic social science. By the meta-methodological platform, we mean the discourse dominating in the scientific community and in the practice of social research, the foundations and roots of the dominant position of which go beyond the limits of science itself and are immersed in the field of its institutional infrastructure.

The usual references to the transitional nature of Russian society, which have been heard for the past three decades, on the one hand, relieve us of theoretical and methodological puzzles, and on the other hand, are clear evidence of stagnation in the field of methodology of social science. From our point of view, the stagnation is due to the preservation and explicit or implicit usage of the revolutionary-dialectical discourse - the theoretical language of science that was developed under the influence of Marxist-Leninist ideology in the institutional environment of Soviet society and was consolidated in culture. The formal rejection of Marxism-Leninism did not lead to the automatic updating of methodological guidelines and tools of scientific research, this requires reflection on the method foundations. The latter involves immersion in the field of institutional infrastructure, identifying its characteristics and determining the impact that institutions have on the semantics and vocabulary of the theoretical language of social science.

In other words, the change of the meta-methodological platform is preceded by the deideologization of science - a procedure carried out through not political, organizational and financial actions (lustration of personnel, changing the nomenclature of scientific institutions and their organizational and legal forms, support for some areas and research programs and the prohibition of others), but scientific tools themselves. The very nature of methodological reflection, its focus on the institutional infrastructure of social science "suggests" that the desired replacement for revolutionary dialectical discourse can be neo-institutionalism, coupled with a number of conceptual approaches that have been developed in modern science in the mid-second half of the twentieth century. Among them, one can distinguish systemic, socio-evolutionary, socio-cultural approaches, cybernetics, synergetics, reality construction, etc. We believe that neo-institutionalism sets a methodological perspective, according to which the formation of a new meta-methodological platform of social science, its modern theoretical language, is carried out.

1. What kind of society do we live in? 
In our study, we will proceed from the assumption that the preservation and usage in social science of a theoretical language belonging to a seemingly long-overcome past is due not only to inertial phenomena in the corporate culture of the scientific community. This kind of inertia generated by the influence of the "Party membership culture" [6], of course, plays a certain role. But to a greater extent it is due to the reproduction of the institutional system that was developed in the society of the Soviet period and continues to exist in the structures of our everyday life. Considered in this perspective, the question of why technologies that actually work and are effective in some conditions, in other ones, on the contrary, can become tools of utopian (ideological) construction of reality and contribute to the simulation of change, for its solution presupposes an answer to another question: what kind of society do we live in?

Perhaps the reasons for the loss of interest in recently still relevant tasks, starting with the political and economic reforms of the 1990s, are that attempts to implement them soon put reformers before the need for serious changes both in the state structure and in management. The experience of the transformations carried out in the country over the past three decades has shown that it is not a matter of their fundamental impracticability because of the so-called "unpreparedness" of society for change. The main obstacle on the path of reforms turned out to be the elites themselves, more precisely, their desire to preserve the status quo developed at the first stage of transformation under all possible scenarios of development. As soon as it was discovered that the systemic consequence of the reforms, with their consistent continuation, could be a social transformation that would radically change the structures of domination and subordination, social and political hierarchy, the order of access of social groups to key resources, the elites lost the political will to a "liberal" (democratic and market) perspective. The uncertainty of the future, near and distant, the resulting risks and direct threats to their dominant position and exclusive right of access to power and financial and economic resources - these, in our opinion, are the main reasons that have caused and are causing the refusal of the society to change initiated by the elites. The refusal was tacit, but became obvious after the default of 1998, which ended the period of political and economic reforms of the 1990s, contributed to the early resignation of President Yeltsin and became a memorable notch in the national consciousness - a symbolic sign of the collapse of the democratic project in its form as it was developed in the late 1980s - early 1990s in line with the ideological completion and denial of perestroika.

The rejection of democratic choice and the coming timelessness, a kind of historical pause taken by the elites with the tacit consent of the masses tired of the hardships of haphazard reform - all this did not mean either inaction of the elites, or the absence of a political course and social dynamics. From our point of view, in relation to the first decade of the XXI century we can talk about a strategic turn, the content of which was the archaization of the basic institutions of society, or social degradation as a technology for the survival of society in a situation where it directly faces the existential question: "to be or not to be?" [9, p. 13]. In historical situations characterized by social dynamics of a stagnating type, one of the ways out is the reconstruction, the revival of archaic institutions based on tradition, on the historical experience of the past and therefore having increased resistance to internal challenges, deviations from order. At the same time, references to tradition can be a trick disguising such new formations under the guise of tradition, which ensure, firstly, the stabilization of disorganized social and interpersonal relations in society at a lower (simplified) level of organization, and secondly, consolidate the dominant position of the ruling elites. The advent of the era of "new barbarism" is accompanied by the accelerated spread of extractive institutions that support the right of pre-emptive appropriation of public wealth by dominant social groups. Reliance on such institutions in economics and politics is associated with the conscious choice of elites [16, p.175]. 
The price of refusal to innovate is economic backwardness, strengthening of authoritarian tendencies in politics and cultural degradation. These are the conditions for achieving stability, restoring institutional order in a situation of deliberate refusal to change. The state of stable ineffective equilibrium achieved here is an institutional trap [12, p. 89] of historical scale; a state in which the pause taken by the elites, which seemed to be a temporary tactical maneuver, becomes a historical intermission - a more or less long period of timelessness. The main content of this period is the selective restoration of the basic institutions of the Soviet, complemented by their superficial modernization. Overestimated attitudes, proclaimed but unrealizable tasks of a modernization nature serve, mainly, to mask archaization.

Perhaps the decisive condition for the successful masking of real trends is the fact that the nature of the Soviet largely remains a "gap" in social science and especially in the mass consciousness, which, with the beginning of perestroika, was characterized by a transition from a positive perception of socialist reality to its negative assessments [18, pp. 42-44], and when the Soviet became the past, there was a reverse turn to its idealization. Despite the high frequency of word usage, Soviet, in fact, is used as a term with a vague meaning, since it has an official meaning, indicating either chronological (1917-1991), or ideological (socialism capitalism), or "national-local" (related to the USSR) features of the phenomenon under study [14, pp. 33-35]. So, in the phrase "Soviet man", the Soviet acts as an adjective, which can mean, depending on the context, both the first, and the second, and the third. From our point of view, the Soviet - despite its grammatical form - is a noun, a concept denoting a certain cultural and historical type. As a type of culture, the Soviet is built over the economic, political and social structures of society, constitutes their systemic quality, that is, a special kind of supersensible reality, and gives this society the form of a whole. In this respect, the Soviet is always "greater" than the totality of its constituent parts. A characteristic feature of this type of culture is the ultimate orientation not on values and the higher principle behind them (God, absolute, world Law), but on super-value - power-potestarity. The latter is the substance, the inner driving force of the Soviet in its social expression, and the Soviet itself can be considered as being-to-power [15, p. 68]. Because of this, the attitude of dominance (as a precondition for solving any tasks, from national to private and domestic) is a characteristic feature of the behavior of social actors of various types and scales.

Potestarity in the world of the Soviet is an archaic kind of power, characterized by a "loose", elementary structure and weak differentiation of functions, tending to domination based on violence and coercion. It is distributed horizontally and vertically in the social organization and determines not only the connection between its parts, but also a kind of interweaving of private and public, public and state. "Society" and "state" are not two relatively independent "entities", they coexist on the principle of "two in one". These are functional projections, functional systems of the Soviet as a whole ${ }^{1}$. The first of them ("society») is characterized by institutional incompleteness, not "growing up" to a civil state. The second ("state") is characterized by functional insufficiency, which manifests itself in the inability of the "state" to meet the key definitions ("social" and "legal", first of all) of the modern state. Perhaps it is also the unwillingness of the ruling corporation representing the Soviet to make fundamental changes to the existing social and state structure.

If the power-potestarity is the internal basis of the existence of the Soviet, then the form of its existence is a corporate-type social organization. The corporate principle permeates the Soviet from top to bottom, which determines the well-known organizational and institutional homogeneity of the social space within which state and public life flows. The place of a particular social group in this structure, determined by the measure of access to public power, mediates the degree of involvement of this group and its constituent individuals in the

\footnotetext{
${ }^{1}$ The mechanism of systemic differentiation of the whole was considered in detail in [19, 135-155].
} 
distribution of significant resources - social, economic, financial, cultural [10, p. 38-41] and, accordingly, "distributions", the share "which is owed" to this group [Bess].

The emergence of the Soviet in the early twentieth century was the response of Russian history to the challenges of industrialization and social and political modernization of the second half of the XIX - early XX centuries. The further evolution of the Soviet Union and its historical fate as a whole were determined and are determined by its plasticity, the ability to simulate in accordance with the challenges of the external and internal environment, while keeping the internal institutional structure relatively unchanged. Simulation of changes, the ability to adapt the institutions and corporate organization of society/state to the requirements of the current moment, reactive responsiveness to the action of momentary factors - these are the limitations beyond which no reform, no modernization of the Soviet Union can go.

2. Limits of digital transformation of public administration

It can be argued with known grounds that modern Russian society (society in the broad sense of the word, including the institutions of statehood) remains Soviet in its basic features. A multi-stage social transformation [21], including perestroika, economic and political reforms of the 1990s, administrative reforms of the 2000s and subsequent years, turned out to be nothing more than a series of attempts to update the Soviet in accordance with the realities of the post-industrial (informational) society, with a new technological order "Industry 4.0" [13]. In the current conditions, digitalization is becoming another resource for the renewal of the Soviet, just as electrification, industrialization, automation of production and management, chemicalization and other campaigns, by their nature, are both technological and ideological cues.

The immanent connection between technology and ideology, which finds practical embodiment in the utopian construction of reality, is one of the sides of the Soviet, thanks to which it has the ability to mimicry, to external, superficial borrowing of changes taking place in the world around us. The depth and thoroughness of such borrowings are fundamentally limited by the level of things and technologies. Changes are allowed in such parameters of the functioning of society as a whole, while maintaining its corporate organization and the dominant position of the ruling elites with their exclusive right of access to power and key resources.

The socio-political mechanism that ensures the preservation of the corporative system of society and the existing hierarchy is the state. To build such a state, the ruling elites have been using the administrative-bureaucratic model for two decades, but without much success, since the effectiveness of this model presupposes the fulfillment of a fundamental requirement: laws rule, not individuals or groups of individuals. For the state structure in modern Russia, this requirement is, in principle, impracticable due to the fact that the fundamental, basic characteristic of Russian statehood, as we indicated above, is corporatism. This is the defining element of the internal environment, which is a kind of prism that refracts external influences and distributes their "traces" in the internal space of the system. It determines the nature of borrowing - what exactly is borrowed, in what areas, for what purposes. It is equally important that it also determines the way of interpretation of the borrowed, including its rethinking and alteration to the needs of the system and in accordance with the existing "local" norms and rules.

The principle (beginning) of corporatism not only mediates borrowing, translating them into the language of local culture and society; thanks to its influence, the mediastinum appears, which sets a certain distance between "our" and "alien". Mentally, this gap manifests itself in the form of an initial distrust of someone else's, in chronological terms - in the form of a delayed, selectively random appeal to a new one, semantically - in the form of a fundamental difference in languages, due to which the institutions that are key for the successful assimilation of someone else's experience (division of state authorities into 
relatively independent branches, human rights and freedoms, inviolability of private life, and the like), either have no analogues in Russian reality, or receive a transformed expression.

Attempts to improve the efficiency and quality of public administration through its digital transformation are mainly aimed at the sphere of public services provided to citizens, organizations and businesses. The literature notes that the indicators used in this case are limited to the assessment of electronic services and the intensity of electronic document flow to the detriment of other possible directions of digitalization of public administration [5, $\mathrm{p}$. 9]. In particular, the effect of digitalization of governance for citizens, business and the state itself is not assessed. As a result, the risks of formal implementation of the project increase, including the adoption and implementation of decisions that do not correspond to the level reached by the leading countries of digitalization [5, p.10].

The degree of danger of routinization of the digitalization project in the field of public administration remains quite high. An analysis of the intermediate results of digital transformation in this area shows the incomparability of trends and the resulting tasks, which are characteristic of countries with a high level of economic development and quality of public administration, on the one hand, and Russia, on the other [4, p. 3]. The challenges facing our society arise in a situation of incomplete modernization of an industrial type, already the third in a row after the first, which occurred at the end of the 19th - beginning of the 20th centuries, and the second - Soviet (1930-1960). One of the reasons for this incompleteness in both the first and second cases was the weak development of the institutions of democracy and the ineffectiveness of public administration closely related to this. Poor quality of public administration remains a factor hindering economic growth in the era of digital transformation [3, p.26].

In new circumstances, the inefficiency of public administration manifests itself in the form of excessive and unjustified interference of the state in economic, social and other processes $[4$, p. 8], a low level of human protection (rights and freedoms, personal data and privacy) [20, p. 12-14], as well as health care and education [3, p. 23-26], a significant scale of corruption (129th place in the world next to Gabon, Malawi, Mali and Azerbaijan according to data for January 2021), a sharp differentiation in income and wages, etc. Administrative and bureaucratic model of the state and state management is inadequate to the requirements of our time. The state exists apart from the leading trends in the development of the world system [7; 17] and hinders the modernization of various spheres of public life.

But not only the state remains Soviet, but also society, which, on the one hand, expresses dissatisfaction with the real state of affairs in the economy, culture, education, health care, the level and quality of life, but on the other hand, as in the old days, "in general the whole "expresses confidence in the government and the political regime, considering the modern" nomenclature "to be the culprits of numerous problems. A certain consensus has developed between the state and society. It is based on an unspoken agreement on the rejection of serious political and economic reforms, which were carried out in a radical form of "storming" in a Bolshevik manner in the 1990s. And as long as this agreement remains in force, the situation of an institutional trap remains, in which society and the state have been for two decades.

\section{Conclusion}

Historically, the task of transforming the Soviet has been on the agenda since the mid-1950s. It was then that the conclusion was made: the natural, human and cultural resources of the reproduction of the Soviet in its previous form are exhausted. But the fundamental question was whether the Soviet was able to change its design in order to adapt to fundamentally new conditions and requirements that the approach of the new world brings with it, no matter how 
it was called in the last half century - the society of scientific and technological progress, the information society, the industrial society of the second generation or something else. History made a breakthrough at the cusp of the millennium, and not only in the field of technology. Political regimes, state structure, economy, social structures and much, much more are changing in the life of society. But the main area affected by the changes is culture and man. The expansion of human freedom, which transcends the borders and barriers that remained from the past and until recently seemed inviolable - national-state, social, religious, ethnic, linguistic, value - captures people regardless of their place of residence, regardless of which of the worlds, to which civilizations and countries they belong. This is an event of a planetary, global scale, drawing the entire human race into the channel of change, since freedom is a natural property of a person, a natural right of any individual, which is based on the fact that he is a human being.

This circumstance creates a perspective beyond which it makes no sense to consider the historical fate of the Soviet and, more importantly, Russia's place in the new world. The key that opens the entrance to this world is not technology, no matter how important their role may seem. By themselves, attempts to create a new technological order, undertaken in isolation from the corresponding changes in culture, politics, and social structure, will not give the desired results. New technologies require a different social structure, flexible, selfregulating, containing a high potential for self-organization and self-government. We need new models of access of social actors to resources and the key of them - to power, and, accordingly, new forms and opportunities for mass participation. We need a different quality of culture, education, healthcare, social environment - all that forms human capital as a decisive factor in the development of society in a globalized world [11, p. 115] and forms the social foundation for the realization of human rights and freedoms. Corporate principles of social organization and archaic extractive institutions should give way to others that are more effective in economic, social, administrative and managerial terms.

All this presupposes the deconcentration of power, the decentralization of state governance and local authorities and the strengthening of democratic institutions in the life of local communities. These and other processes are changing the structure of social space, which not only opens up opportunities, but creates the need to switch to new technologies in the field of economics, politics, and social relations.

\section{References}

1. V. B. Aleksandrov, Ideya tsifrovogo gosudarstva pered litsom russkoy kul'turnoy traditsii ponimaniya smysla gosudarstvennoy vlasti, Upravlencheskoye konsul'tirovaniye, 2, 16-21 (2020)

2. O. E. Bessonova, Razdatochnaya ekonomika Rossii (Izd-vo «Rossiyskaya politicheskaya entsiklopediya», 2006)

3. Ye. I. Dobrolyubova, Otsenka kachestva gosudarstvennogo upravleniya $v$ Rossii $i$ drugikh krupnykh ekonomikakh mira, Gosudarstvennaya sluzhba, 1 (129), 19-27 (2021)

4. Ye. I. Dobrolyubova, Kachestvo gosudarstvennogo upravleniya skvoz' prizmu mezhdunarodnykh reytingov $i$ otsenok rossiyskikh ekspertov, Materialy nauchno-prakticheskogo seminara «Kachestvo gosudarstvennogo upravleniya v Rossii: perspektivy rosta» (RANKhiGS, 2021). Access mode: https://ipei.ranepa.ru/ru/konferenciictgu/4735-v-akademii-obsudili-prioritetnye-napravleniya-povysheniya-kachestvagosudarstvennogo-upravleniya

5. Ye. I. Dobrolyubova, V. N. Yuzhakov, A. N. Starostina, Tsifrovaya transformatsiya gosudarstvennogo upravleniya: otsenka rezul'tativnosti i effektivnosti (Izd. dom «Delo» RANKhiGS, 2021) 
6. A. V. Gordon, Kul'tura partiynosti $i$ opyt sovetskogo istorioznaniya, Rossiya i sovremennyy mir, 3 (64), 160-180 (2009)

7. Gosudarstvo v politicheskoy nauke i sotsial'noy real'nosti XXI veka, IMEMO RAN (Izdvo «Ves' mir», 2021)

8. Istoriya Vsesoyuznoy kommunisticheskoy partii (bol'shevikov): kratkiy kurs (Izd-vo TSK VKP(b) «Pravda», 1938)

9. A. A. Kara-Murza, «Novoye varvarstvo» kak problema rossiyskoy tsivilizatsii (IF RAN, 1995)

10. S. Kordonskiy, Rossiya. Pomestnaya federatsiya (Izd-vo «Yevropa», 2010)

11. V. Mau, Chelovecheskiy kapital: vyzov dlya Rossii, Voprosy ekonomiki, 7 (2012)

12. V. M. Polterovich, Elementy teorii reform (ZAO «Izdatel'stvo «Ekonomika», 2007)

13. K. Schvab, N. Devis, Tekhnologii Chetvertoy promyshlennoy revolyutsii (Eksmo, 2018)

14. N. A. Skorobogatskaya, V. V. Skorobogatskiy, Sovetskoye: istoriko-kul'turnyy kontekst fenomena, Antinomii, 20, 33-74 (2020)

15. V. V. Skorobogatskiy, Sovetskoye: genezis, rastsvet, puti transformatsii $v$ postkommunisticheskuyu epokhu (2021)

16. I. V. Starodubrovskaya, Drama modernizatsionnoy teorii. Stat'ya 2. Posle krizisa: razvilki i tupiki sovremennoy modernizatsionnoy teorii, Obshchestvennyye nauki i sovremennost', 2, 170-181 (2019)

17. K. O. Telin, Vmesto mifa: «moment istiny» dlya gosudarstva, Polis. Politicheskiye issledovaniya, 5, 184-191 (2021)

18. A. Yurchak, Eto bylo navsegda, poka ne konchilos'. Posledneye sovetskoye pokoleniye (Novoye literaturnoye obozreniye, 2014)

19. V. N. Yuzhakov, Organizatsiya protsessa razvitiya: ontologiya $i$ metodologiya upravleniya razvitiyem (2011)

20. V. N. Yuzhakov, Ye. I. Dobrolyubova, A. N. Pokida, N. V. Zybunovskaya, Deyatel'nost' gosudarstvo po zashchite okhranyayemykh zakonom tsennostey $v$ period pandemii: otsenka grazhdan, Voprosy gosudarstvennogo i munitsipal'nogo upravleniya, 3, 7-30 (2021)

21. T. I. Zaslavskaya, Sovremennoye rossiyskoye obshchestvo: sotsial'nyy mekhanizm transformatsii (Delo, 2004) 